\title{
ECOLOGICAL-EVOLUTIONARY RELATIONSHIPS IN Passiflora alata FROM RIO GRANDE DO SUL, BRAZIL
}

\author{
KOEHLER-SANTOS, P., LORENZ-LEMKE, A. P., \\ SALZANO, F. M. and FREITAS, L. B. \\ Departamento de Genética, Instituto de Biociências, \\ Universidade Federal do Rio Grande do Sul - UFRGS, Porto Alegre, RS, Brazil \\ Correspondence to: Patricia Koehler-Santos, Departamento de Genética, Instituto de Biociências, \\ Universidade Federal do Rio Grande do Sul - UFRGS, Porto Alegre, RS, Brazil, \\ e-mail: patriciakoehler_bio@yahoo.com.br
}

Received February 2, 2005 - Accepted March 21, 2005 - Distributed August 31, 2006

(With 2 figures)

\begin{abstract}
The geographical distribution, ecological characteristics, flowering and fruiting times, and pollinating agents of Passiflora alata are considered and related to molecular genetic data gathered simultaneously. The first report on this species in Rio Grande do Sul was made in 1934, only in cultivated gardens. Approximately 20 years later, however, the species was already classified as efferata (wild) in Porto Alegre's suburbs. The data presented here, together with the DNA investigations, indicate that $P$. alata is actively colonizing previously unoccupied areas of this region.
\end{abstract}

Keywords: Passiflora alata, geographical distribution, phenology, colonization process, plant evolution.

\section{RESUMO}

\section{Relações ecológico-evolutivas em Passiflora alata do Rio Grande do Sul, Brasil}

A distribuição geográfica, as características ecológicas, as épocas de florescimento e frutificação, e os agentes polinizadores de Passiflora alata são considerados e relacionados a estudos genético-moleculares desenvolvidos simultaneamente. O primeiro registro da espécie no Rio Grande do Sul foi feito em 1934, apenas em área cultivada. Cerca de 20 anos depois, no entanto, a espécie já era classificada como efferata (selvagem) nos subúrbios de Porto Alegre. Os dados aqui apresentados, junto com as investigações de DNA, indicam que $P$. alata está colonizando ativamente áreas previamente não ocupadas desta região.

Palavras-chave: Passiflora alata, distribuição geográfica, fenologia, processo colonizador, evolução vegetal.

\section{INTRODUCTION}

As part of a long-term project of investigation of the genus Passiflora by our group (Muschner et al., 2003; Lorenz-Lemke et al., 2005) we studied Passiflora alata Curtis in detail in the Brazilian state of Rio Grande do Sul. The geographical proximity to the place where we work provided an opportunity to make detailed field and ecological observations, that can be related to the geneticmolecular studies that we were already making on this and related species.

$P$. alata is classified in the family Passifloraceae, occurring in the Atlantic Rain Forest, especially on the periphery of humid woods at low altitude, as well as in forest patches of varying size, near the coast. The species has a wide distribution in Brazil, being reported from the states of Bahia, Espírito Santo, Federal District, Mato Grosso do Sul, Minas Gerais, Paraná, Pará, Rio de Janeiro, Rio Grande do Sul, São Paulo and Santa Catarina. Moreover, it has been found in Argentina, Paraguay, and Peru (Killip, 1938; Feller, 1967; Sacco, 1980; Pessoa, 1994, 1997; Cervi, 1996, 1997; Cervi \& Santos, 2000; Deginani, 2001; Bernacci, 2003).

The first published report of P. alata in Brazil dates from 1938, when Killip (1938) reported it as an 
apparently native species in the majority of Brazilian states. Rambo (1951), Sacco (1962, 1980) and Feller (1967), however, referred to it as a cultivated species in Rio Grande do Sul, with the possibility of becoming wild; some years later Mondin (2001) classified it as subspontaneous. The factor that determined the present study was our observation that the species was abundant in the wild condition in many parts of the state, characterizing a possible case of a taxon in an active process of colonizing open spaces. Additionally, since the species is concentrated mainly in the central-eastern part of the Brazilian territory, the populations studied could represent a good model of species living at the borderline of their geographical range.

\section{MATERIAL AND METHODS}

The territory of Rio Grande do Sul is situated between $49^{\circ} 43^{\prime}$ and $57^{\circ} 41^{\prime} \mathrm{W}$. longitude and $27^{\circ} 04^{\prime}$ and $33^{\circ} 45^{\prime}$ of $\mathrm{S}$. latitude, and represents the southern limit of the distribution of many tropical species, being described as a transition area between biogeographical provinces (Mondin \& Baptista, 1996; Jarenkow \& Sobral, 2000). According to Teixeira et al. (1986) Rio Grande do $\mathrm{Sul}$ is divided into six geomorphologic provinces (Araucaria Plateau, Campanha Plateau, Central Depression, Coastal Plain, Missions Plateau, and South Rio Grande Plateau) (Fig. 1) and seven phytoecologic facies (Deciduous Seasonal Forest, Dense Rain Forest, Mixed Rain Forest, Savannah, Semideciduous Seasonal Forest, Steppe, and Steppic Savannah), as well as two areas with special ecological conditions (Ecological Tension and Pioneer Formations). The latter roughly coincide with the geomorphologic boundaries.

The six geomorphologic and the nine phytoecologic regions of the state were searched, and P. alata material collected. For each specimen a sample was pressed and dried, and subsequently deposited at the ICN Herbarium, Botany Department, Biosciences Institute, Federal Uni-

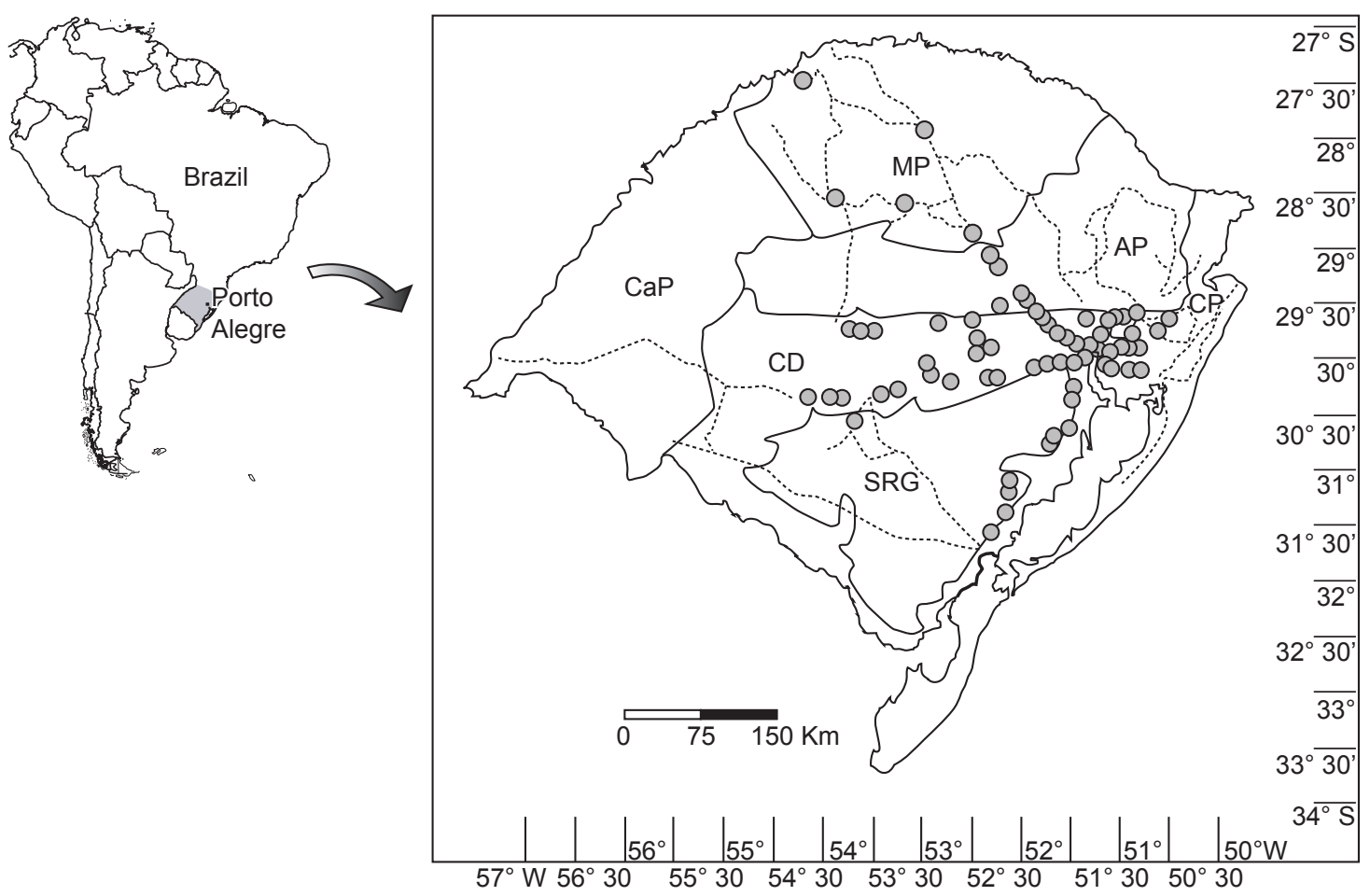

Fig. 1 - Map of South America (upper left) and enlarged map of Rio Grande do Sul, showing the places of collection (circles), the state's geomorphologic regions (AP: Araucaria Plateau; CaP: Campanha Plateau; CD: Central Depression; CP: Coastal Plain; MP: Missions Plateau; and SRG: South of Rio Grande Plateau) separated by full lines, and the routes followed in our field trips (dotted lines). 
versity of Rio Grande do Sul. Subsamples were used for DNA studies, reported elsewhere (Koehler-Santos et al., 2005). Each collection point was georeferenced in accordance with standard procedures, using a Garmin GPS apparatus.

To access previous records of $P$. alata occurrence in Rio Grande do Sul, a survey was made (by electronic mail or personal visit) of the following herbaria: 1. HAS (Rio Grande do Sul Zoobotanical Foundation); 2. HUCS (Caxias do Sul University); 3. HURG (Federal University of Rio Grande Foundation); 4. ICN (Federal University of Rio Grande do Sul); 5. MPUC (Pontifical Catholic University of Rio Grande do Sul); 6. PACA (Anchieta Research Institute); 7. PEL (Federal University of Pelotas); 8. RSPF (Passo Fundo University); and 9. SMDB (Federal University of Santa Maria).

For each plant observed, besides the geographical coordinates, the following observations were registered: (a) presence/absence of floral buds or open flowers; (b) presence/absence of fruits; (c) when fruits were present, indications of predation; (d) presence/absence of pollinators and/or flower visitors; (e) environmental characterization (type of associated vegetation, evidence of human interference); and (f) presence/absence of associated Passiflora species.

\section{RESULTS AND DISCUSSION}

No records of $P$. alata were found in the HAS and MPUC herbaria, but a total of 37 occurrences were registered in the seven institutions listed in Table 1. The earliest dates from March 15, 1934, a record made by Rambo (1951), who found it in cultivated form in São Leopoldo, about $34 \mathrm{~km}$ north of Porto Alegre (PACA registration number 1275); the same researcher found wild $P$. alata in the suburbs of Porto Alegre on November 22, 1956 (PACA n ${ }^{\circ}$. 59215). After 1956, a series of occurrences have been documented of the species both in cultivated and wild plots.

Table 2 shows the places where we have collected $P$. alata, and Table 3 the routes we followed without finding it (see also Fig. 1). Listed in Table 2 are the 50 places of collection, with their geographical coordinates, that are shown graphically in Fig. 1. In all 192, specimens were collected and many more were observed. In many instances only one individual was sampled in a collecting site.
P. alata was found in five of the six geomorphologic regions (exception: Campanha Plateau), and in eight of the nine phytoecologic regions (exception: Steppic Savannah). No morphologic variant was found in the state, confirming observations reported for other places in Brazil. Practically all plants were observed or collected in well-illuminated places disturbed by humans, like small woods near roads. No association with a specific type of vegetation was recorded.

Most plants were seen or collected in the Coastal Plain and Central Depression geomorphologic regions. In the Coastal Plain the main vegetation is of the Pioneer Formation type, and $P$. alata occurs in the more inland subtype, of riverine influence. In the Central Depression, plants of this species occur mainly in areas of Deciduous Seasonal Forests and Ecological Tension zones (with interpenetrating floras of two or more plant formations). Individuals were also collected in the Southern Rio Grande Plateau, a region characterized by a savannah-type vegetation, and eastern areas of the Semideciduous Seasonal Forest. On the Araucaria Plateau P. alata was seen or collected only in low altitude places. The lower number observed in the Mission Plateau region may be related to the type of economic activity prevalent there (grain cultivation) that extends the fields to quite near the roads. Both human presence (in the north grain production, in the south cattle rearing) and the type of dry climate prevalent in the Campanha Plateau may explain the absence of $P$. alata records there. This species occurs mainly on soils of the textural horizon type B, and to a lesser degree on litholic neosoils. The first are characterized by higher concentrations of clay than those found in under or upper strata, while the latter are very recent deep or plain formations which occur in several conditions of altitude and drainage (Streck et al., 2002).

The plants were collected mainly along paved roads, and were seldom seen near unpaved ones, even when they occurred in nearby orchards. For example, our first trip along the RS 474 highway, which connects Santo Antônio da Patrulha to RS 239, occurred just after it was paved in November, 2001, and no P. alata specimens were found, even some distance from it. Two years later in October, 2003 several young plants, without flowers, were seen and collected. The difference may be due to the fact that along the paved roads 
TABLE 1

Herbarium information for P. alata in Rio Grande do Sul.

\begin{tabular}{|c|c|c|c|c|}
\hline $\begin{array}{c}\text { Herbarium } \\
\text { identification }\end{array}$ & $\begin{array}{c}\text { Registration } \\
\text { number }\end{array}$ & Locality & $\begin{array}{c}\text { Date of } \\
\text { collection }\end{array}$ & Status \\
\hline HUCS & 1771 & Caxias do Sul & $22 / 07 / 1986$ & cultivated \\
\hline \multirow[t]{4}{*}{ HURG } & 000723 & Arroio Bolacha, Rio Grande & $26 / 10 / 1983$ & wild \\
\hline & 000990 & Vila da Quinta, Rio Grande & $02 / 11 / 1982$ & wild \\
\hline & 001034 & St. Hillaire, Viamão & $17 / 03 / 1982$ & wild \\
\hline & 001998 & Reserva Ecológica do Taim, Rio Grande & $12 / 09 / 2000$ & wild \\
\hline \multirow[t]{11}{*}{$\mathrm{ICN}$} & 67234 & Belém Velho, Porto Alegre & $04 / 1987$ & no data \\
\hline & 94457 & Estação Experimental, Viamão & $09 / 01 / 1990$ & no data \\
\hline & 94773 & Agronomia, Porto Alegre & $06 / 1987$ & no data \\
\hline & 117541 & Dom Pedro de Alcântara & $24 / 05 / 1997$ & cultivated \\
\hline & 115084 & Morro Grande, Viamão & $21 / 10 / 1998$ & wild \\
\hline & 117715 & Morro do Côco, Dom Pedro de Alcântara & $05 / 12 / 1997$ & cultivated \\
\hline & 94775 & Lomba do Pinheiro, Porto Alegre & $07 / 1987$ & cultivated \\
\hline & $\begin{array}{l}N^{\circ} \text { II } 27 / 26 / 1 / 3 \\
\text { Schultz } 374\end{array}$ & Porto Alegre & 19/04/1938 & cultivated \\
\hline & 4827 & Viamão & $06 / 1967$ & cultivated \\
\hline & 62573 & Porto Alegre & $20 / 03 / 1985$ & no data \\
\hline & 132158 & Ponta Grossa, Porto Alegre & $17 / 04 / 2003$ & wild \\
\hline \multirow[t]{4}{*}{ PACA } & 1275 & São Leopoldo & $15 / 03 / 1934$ & cultivated \\
\hline & 7183 & São Leopoldo & $06 / 09 / 1954$ & cultivated \\
\hline & 59215 & Vila Manresa (Morro da Glória), Porto Alegre & $22 / 11 / 1956$ & wild \\
\hline & 69744 & I.A.S. (Instituto Agronômico do Sul), Pelotas & $14 / 02 / 1962$ & cultivated \\
\hline \multirow[t]{2}{*}{ PEL } & 4548 & São Lourenço do Sul & $29 / 05 / 1963$ & cultivated \\
\hline & 10018 & Between Km 321 and BR 116, Tapes & $20 / 06 / 1988$ & wild \\
\hline \multirow[t]{2}{*}{ RSPF } & 6362 & Espumoso & $20 / 10 / 1998$ & wild \\
\hline & 7232 & Montenegro & $16 / 03 / 2003$ & wild \\
\hline \multirow[t]{13}{*}{ SMDB } & 4775 & Boca do Monte, Santa Maria & $31 / 10 / 1993$ & wild \\
\hline & 6510 & Santa Maria & $01 / 1996$ & wild \\
\hline & 3201 & Jardim Botânico, UFSM & $09 / 06 / 1987$ & no data \\
\hline & 8388 & São João do Polêsine & $27 / 01 / 2000$ & wild \\
\hline & 8384 & São João do Polêsine & $15 / 04 / 2000$ & wild \\
\hline & 8390 & São João do Polêsine & no data & wild \\
\hline & 8391 & São João do Polêsine & $11 / 06 / 2000$ & wild \\
\hline & 8392 & São João do Polêsine & $01 / 11 / 1999$ & wild \\
\hline & 8394 & São João do Polêsine & $22 / 10 / 1999$ & wild \\
\hline & 8395 & São João do Polêsine & $27 / 11 / 1999$ & wild \\
\hline & 8397 & São João do Polêsine & $14 / 01 / 2000$ & wild \\
\hline & 8386 & São João do Polêsine & $29 / 02 / 2000$ & wild \\
\hline & 8400 & São João do Polêsine & $30 / 05 / 2000$ & wild \\
\hline
\end{tabular}

the cleaning of the adjacent terrain is more drastic, leading to the extinction of competitor species and the opening of space for P. alata.

Fig. 2 shows information concerning the phenology of $P$. alata, as observed in Rio Grande do Sul. The presence of only the vegetative state was observed in four months, two in winter (July, August) and two in summer (December, January). Floral buds and flowers were consistently seen in all other months, while fruits occurred in March, May, September, October, and November. Previous records by other authors indicate some variation among Brazilian regions both in flowering or fruiting times, with flowers present almost all year round, and fruit during five months (Sacco, 1962, 1980; Koschnitzke, 1993; Cervi, 1996, 1997; Varassin \& Silva, 1999; Cervi \& Santos, 2000; Bernacci, 2003).

The large flowers and odoriferous filaments of $P$. alata favor pollination by bees, and among its main pollinating agents are bees of the genus Xylocopa (Hymenoptera, Anthophoridae) (Sazima 
TABLE 2

Collection sites for P. alata in Rio Grande do Sul.

\begin{tabular}{|c|c|c|}
\hline Locality & Geographical coordinates $^{1}$ & Geomorphologic region \\
\hline Esquina Gaúcha & $27^{\circ} 27^{\prime}-54^{\circ} 12^{\prime}$ & Missions Plateau \\
\hline Navegantes, Crissiumal & $27^{\circ} 30^{\prime}-54^{\circ} 07^{\prime}$ & Missions Plateau \\
\hline Sarandi & $27^{\circ} 58^{\prime}-52^{\circ} 55^{\prime}$ & Missions Plateau \\
\hline Ibirubá & $28^{\circ} 39^{\prime}-53^{\circ} 06^{\prime}$ & Missions Plateau \\
\hline Cruz Alta & $28^{\circ} 39^{\prime}-53^{\circ} 38^{\prime}$ & Missions Plateau \\
\hline Marques de Souza & $29^{\circ} 17^{\prime}-52^{\circ} 09^{\prime}$ & Araucaria Plateau \\
\hline São Vendelino & $29^{\circ} 22^{\prime}-51^{\circ} 23^{\prime}$ & Araucaria Plateau \\
\hline Bom Princípio & $29^{\circ} 26^{\prime}-51^{\circ} 21^{\prime}$ & Araucaria Plateau \\
\hline Três Coroas & $29^{\circ} 32^{\prime}-50^{\circ} 47^{\prime}$ & Transition zone (CD-AP) \\
\hline Estrela & $29^{\circ} 34^{\prime}-51^{\circ} 54^{\prime}$ & Araucaria Plateau \\
\hline Fazenda Vilanova & $29^{\circ} 35^{\prime}-51^{\circ} 50^{\prime}$ & Araucaria Plateau \\
\hline Igrejinha & $29^{\circ} 36^{\prime}-50^{\circ} 48^{\prime}$ & Transition zone (CD-AP) \\
\hline São Sebastião do Caí & $29^{\circ} 38^{\prime}-51^{\circ} 19^{\prime}$ & Transition zone (CD-AP) \\
\hline Venâncio Aires & $29^{\circ} 39^{\prime}-52^{\circ} 11^{\prime}$ & Central Depression \\
\hline Rolante & $29^{\circ} 40^{\prime}-50^{\circ} 40^{\prime}$ & Coastal Plain \\
\hline Portão & $29^{\circ} 40^{\prime}-51^{\circ} 16^{\prime}$ & Transition zone (CD-AP) \\
\hline Tabaí & $29^{\circ} 40^{\prime}-51^{\circ} 45^{\prime}$ & Araucaria Plateau \\
\hline Taquara & $29^{\circ} 42^{\prime}-50^{\circ} 49^{\prime}$ & Coastal Plain \\
\hline Taquari & $29^{\circ} 42^{\prime}-51^{\circ} 51^{\prime}$ & Central Depression \\
\hline Santa Maria & $29^{\circ} 43^{\prime}-53^{\circ} 40^{\prime}$ & Central Depression \\
\hline Pinheirinhos, Santo Antônio da Patrulha & $29^{\circ} 44^{\prime}-50^{\circ} 37^{\prime}$ & Coastal Plain \\
\hline Restinga Seca & $29^{\circ} 44^{\prime}-53^{\circ} 27^{\prime}$ & Central Depression \\
\hline Novo Cabrais & $29^{\circ} 45^{\prime}-53^{\circ} 03^{\prime}$ & Central Depression \\
\hline Montenegro & $29^{\circ} 49^{\prime}-51^{\circ} 24^{\prime}$ & Central Depression \\
\hline Morungava, Gravataí & $29^{\circ} 52^{\prime}-50^{\circ} 54^{\prime}$ & Coastal Plain \\
\hline Itacolomi, Gravataí & $29^{\circ} 52^{\prime}-50^{\circ} 59^{\prime}$ & Coastal Plain \\
\hline Santo Antônio da Patrulha & $29^{\circ} 53^{\prime}-50^{\circ} 32^{\prime}$ & Coastal Plain \\
\hline Nova Santa Rita & $29^{\circ} 53^{\prime}-51^{\circ} 15^{\prime}$ & Central Depression \\
\hline Glorinha & $29^{\circ} 54^{\prime}-50^{\circ} 43^{\prime}$ & Coastal Plain \\
\hline Canoas & $29^{\circ} 54^{\prime}-51^{\circ} 14^{\prime}$ & Central Depression \\
\hline Gravataí & $29^{\circ} 57^{\prime}-50^{\circ} 57^{\prime}$ & Coastal Plain \\
\hline Porto Alegre & $30^{\circ} 02^{\prime}-51^{\circ} 12^{\prime}$ & Coastal Plain \\
\hline Eldorado do Sul & $30^{\circ} 05^{\prime}-51^{\circ} 37$ & Central Depression \\
\hline Viamão & $30^{\circ} 06^{\prime}-50^{\circ} 59^{\prime}$ & Coastal Plain \\
\hline Capão da Porteira, Viamão & $30^{\circ} 07^{\prime}-50^{\circ} 41^{\prime}$ & Coastal Plain \\
\hline Águas Claras, Viamão & $30^{\circ} 09^{\prime}-50^{\circ} 55^{\prime}$ & Coastal Plain \\
\hline Butiá & $30^{\circ} 09^{\prime}-52^{\circ} 01^{\prime}$ & Central Depression \\
\hline Minas do Leão & $30^{\circ} 09^{\prime}-52^{\circ} 04^{\prime}$ & Central Depression \\
\hline Guaíba & $30^{\circ} 12^{\prime}-51^{\circ} 24^{\prime}$ & South Rio Grande Plateau \\
\hline Cachoeira do Sul & $30^{\circ} 14^{\prime}-52^{\circ} 42^{\prime}$ & Central Depression \\
\hline Capané, Cachoeira do Sul & $30^{\circ} 17^{\prime}-53^{\circ} 06^{\prime}$ & Central Depression \\
\hline Barra do Ribeiro & $30^{\circ} 18^{\prime}-51^{\circ} 25^{\prime}$ & South Rio Grande Plateau \\
\hline Caçapava do Sul & $30^{\circ} 37^{\prime}-53^{\circ} 32^{\prime}$ & South Rio Grande Plateau \\
\hline Sentinela do Sul & $30^{\circ} 39^{\prime}-51^{\circ} 34^{\prime}$ & South Rio Grande Plateau \\
\hline Balneário Pinvest, Tapes & $30^{\circ} 40^{\prime}-51^{\circ} 23^{\prime}$ & Coastal Plain \\
\hline Vila Arroio Teixeira, Tapes & $30^{\circ} 40^{\prime}-51^{\circ} 23^{\prime}$ & Coastal Plain \\
\hline Eldorado do Sul & $31^{\circ} 03^{\prime}-51^{\circ} 20^{\prime}$ & South Rio Grande Plateau \\
\hline São Lourenço do Sul & $31^{\circ} 14^{\prime}-52^{\circ} 01^{\prime}$ & South Rio Grande Plateau \\
\hline Cerrito Alegre, Pelotas & $31^{\circ} 33^{\prime}-52^{\circ} 14^{\prime}$ & South Rio Grande Plateau \\
\hline Vila Assumpção, Pelotas & $31^{\circ} 46^{\prime}-52^{\circ} 20^{\prime}$ & South Rio Grande Plateau \\
\hline
\end{tabular}

${ }^{1}$ Geographical coordinates: south (S); and west (W). 
\& Sazima, 1989; Koschnitzke, 1993, Koschnitzke \& Sazima, 1997; Varassin \& Silva, 1999; Varassin et al., 2001). On the other hand, Varassin \& Silva (1999) and Varassin et al. (2001) observed that bees of the genus Apis (Hymenoptera, Apidae) are predators of $P$. alata plants, since they take pollen from it, but do not perform the pollinization process. Our observations partially agree with this information. We continuously followed one P. alata plant cultivated on the campus of our university where our Department is located, commonly visited by Apis bees, and observed that although the fruit is formed it never matured over the four years (2000-2004) of our observation. However, in wild specimens distributed in woods at the periphery of the campus, fertile plants occur which are visited by both Apis and Xylocopa bees.

Seed dispersion in the Passifloraceae is generally made by birds and bats, attracted by the color and smell of the mature fruit (Semir \& Brown, 1975); however, small terrestrial mammals were also observed eating Passiflora fruit (Williams et al., 2000). Fruit collected by us during the trips showed tooth marks that were identified by our colleagues, A. Kindel and T. R. O. Freitas, as being made by the opossum Didelphis albiventris and the arboreal rodent Oryzomys subflavus. Therefore, these animals, in addition to other still unidentified agents, should be considered as seed disseminators and predators in our region.

The molecular-genetic studies we performed on P. alata are being reported in full elsewhere (Koehler-Santos et al., 2005). However, a description of the main findings related to the present observations is in order. Briefly, we studied representatives of all populations found in Rio Grande do Sul, in relation to three nuclear DNA systems [ribosomal Internal Transcribed Spacers or ITS; a partial segment of the glyceraldehyde 3-phosphate dehydrogenase ( $G 3 p d h$ or $g p d$ ), and the second intron of the LEAFY genes], as well as eight plastid regions. While the latter did not show variability, the three nuclear genes provided important information. Characteristics of variability from all three clearly indicated that $P$. alata is experiencing a population expansion. In addition, their high intrapopulation variance and the absence of a clear geographical structure, also suggest that the $P$. alata populations sampled have arrived recently in their present areas of distribution.
The effective invasion of an environment by new species is influenced by three factors: the number of individuals (or their gametes) which are introduced; the internal characteristics of the invading species; and the environmental susceptibility to the invasion of new species. The latter involves many factors, such as climate, the amount of environmental disturbance due to human presence or its products, and the competitive ability of the resident species. Other factors are soil type, presence or absence of herbivores, pathogenic agents, and facilitating effects of the resident vegetation (Decker, 1936; Lonsdale, 1999; Davis et al., 2000). In the specific case under discussion, it is possible that the presence of dispersion and pollinization agents that are already acting on other native species of Passiflora present in Rio Grande do Sul may have facilitated the colonization process of $P$. alata. It is important to mention that although these other species of Passiflora occur in the state, they are never found in association with $P$. alata. Therefore, the latter might be competing with other taxa. Historical, genetic, morphological, and the ecological characteristics presented in this paper, together with the easy adaptation of $P$. alata to cultivation, all indicate its plastic nature and suggest that the taxon is undertaking an active process of colonization of new territories.

Acknowledgments - We thank Drs. Andreas Kindel (Department of Ecology, Biosciences Institute, Federal University of Rio Grande do Sul) and Thales R.O. Freitas (Department of Genetics of the same Institute) for help in identifying the tooth marks found on P. alata fruits; and Dr. Cláudio A. Mondin (Biosciences Faculty, Pontifical Catholic University of Rio Grande do Sul) for the critical reading of a first version of this manuscript. Our research is supported by the Programa de Apoio a Núcleos de Excelência (PRONEX), Conselho Nacional de Desenvolvimento Científico e Tecnológico (CNPq), Fundação de Amparo à Pesquisa do Estado do Rio Grande do Sul (FAPERGS), and Pró-Reitoria de Pesquisa da Universidade Federal do Rio Grande do Sul (PROPESQ-UFRGS).

\section{REFERENCES}

BERNACCI, L. C., 2003, Passifloraceae, pp. 247-274. In: M. G. L. Wanderley, G. J. Shepherd, T. S. Melhem, A. M. Giulietti \& M. Kirizawa (eds), Flora fanerogâmica do Estado de São Paulo, Fundação de Amparo à Pesquisa do Estado de São Paulo (FAPESP), São Paulo.

CERVI, A. C., 1996, Passifloraceae da região de Carangola - Minas Gerais, Brasil. Pabstia, VII: 1-32.

CERVI, A. C., 1997, Passifloraceae do Brasil. Estudo do gênero Passiflora L., subgênero Passiflora. Fontqueria, 45: 1-92. 
TABLE 3

Places where P. alata was not found in Rio Grande do Sul ${ }^{1}$.

\begin{tabular}{|c|c|c|}
\hline Road & Detail & Date \\
\hline RS 344 & Between Santa Rosa and Entre-Ijuis & apr/2002 \\
\hline RS 155 & Between BR 468 and Ijuí & apr/2002 \\
\hline BR 468 & Between Palmeira das Missões and RS 155 & apr/2002 \\
\hline RS 569 & Between Palmeira das Missões and Sarandi & apr/2002 \\
\hline BR 285 & Between Lagoa Vermelha and Vacaria & $\mathrm{mar} / 2004$ \\
\hline RS 324 & Between Passo Fundo and Veranópolis & mar/2004 \\
\hline BR 386 & Between Carazinho and Pouso Novo & apr/2002 \\
\hline BR 285 & Between Entre-Ijuis and Ijuí & apr/2002 \\
\hline BR 158 & Between RS 155 and Cruz Alta & apr/2002 \\
\hline BR 116 & Between Vacaria and Caxias do Sul & $\mathrm{mar} / 2004$ \\
\hline RS 223/BR 377 & Between Cruz Alta and Tio Hugo & apr/2002 \\
\hline BR 158 & Between Cruz Alta and Santa Maria & nov/2003 \\
\hline VRS 24 & Between Ibirubá and Fortaleza dos Valos & oct $/ 2003$ \\
\hline RS 110 & Between Bom Jesus and São Francisco de Paula & $\mathrm{jul} / 2003$ \\
\hline RS 122 & Between Ipê and Caxias do Sul & $\mathrm{mar} / 2004$ \\
\hline RS 020 & Between Cambará do Sul and São Francisco de Paula & jun/2003 \\
\hline RS 334 & Between BR 386 and RS 223 & oct $/ 2003$ \\
\hline RST 453 & Caxias do Sul & $\operatorname{mar} / 2004$ \\
\hline RS 122 & Between Caxias do Sul and Farroupilha & $\mathrm{mar} / 2004$ \\
\hline BR 116 & Between Caxias do Sul and Nova Petrópolis & $\operatorname{mar} / 2004$ \\
\hline RST 453 & Between Bento Gonçalves and Farroupilha & mar/2004 \\
\hline RST 470 & Between Bento Gonçalves and São Vendelino & mar/2004 \\
\hline RS 235 & Between Nova Petrópolis and Gramado & $\operatorname{mar} / 2004$ \\
\hline RS 389 & Between Torres and Imbé & $\mathrm{feb} / 2004$ \\
\hline RS 474 & Between Santo Antônio da Patrulha and RS 239 & nov/2001 \\
\hline RS 484 & Between Maquiné and Barra do Ouro & $\operatorname{mar} / 2002$ \\
\hline BR 101 & Between Maquiné and Capivari do Sul & $\mathrm{mar} / 2002$ \\
\hline RS 030 & Between Santo Antônio da Patrulha and BR 290 & nov/2001 \\
\hline BR 290 & Between Porto Alegre and Uruguaiana & $\mathrm{jul} / 2002$ \\
\hline BR 158 & Between BR 293 and BR 290 & aug/2002 \\
\hline BR 153 & Between BR 290 and BR 392 & oct/2002 \\
\hline BR 392 & Between BR 153 and Caçapava do Sul & oct $/ 2002$ \\
\hline RS 625 & Between RS 353 and BR 392 & oct $/ 2002$ \\
\hline BR 392 & Between BR 290 and Pelotas & sep/2002 \\
\hline BR 293 & Between Santana do Livramento and Pelotas & aug/2002 \\
\hline
\end{tabular}

${ }^{1}$ The information given refers to field notes registered during the trips; some local roads without identification could not be included in this list. The road codes could have changed in the intervening years.

CERVI, A. C. \& SANTOS, E. P., 2000, Flórula do Morro dos Perdidos, Serra de Araçatuba, Estado do Paraná, Brasil: Passifloraceae. Est. Biol., PUCPR, Curitiba, 46: 25-47.

DAVIS, M. A., GRIME, J. P. \& THOMPSON, K., 2000, Fluctuating resources in plant communities: a general theory of invasibility. J. Ecol., 88: 528-534.

DECKER, J. S., 1936, Aspectos biológicos da flora brasileira. Rotermund, São Leopoldo, RS, 640p.

DEGINANI, N. B., 2001, Las especies argentinas del género Passiflora (Passifloraceae). Darwiniana, 39: 43-129.
FELLER, M., 1967, Estudo do gênero Passiflora no Rio Grande do Sul. Est. Leopold., 3: 17-43.

JARENKOW, J. A. \& SOBRAL, M., 2000, Nota sobre a ocorrência de algumas angiospermas no Rio Grande do Sul, Brasil. Napaea, 12:21-25

KILLIP, E. P., 1938, The American species of Passifloraceae. Botanical Series, Field Mus. Nat. Hist., 19: 1-613.

KOEHLER-SANTOS, P. et al., 2005, Evolutionary implications of the intrapopulation diversity of Passiflora alata. Biol. J. Linn. Soc. (submitted). 


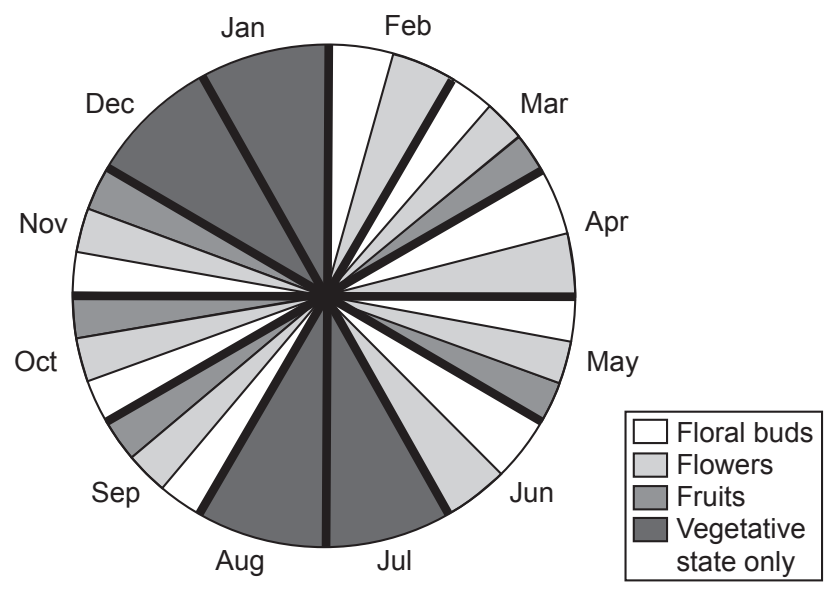

Fig. 2 - Phenology of P. alata observed in the state of Rio Grande do Sul.

KOSCHNITZKE, C., 1993, Morfologia e biologia floral de cinco espécies de Passiflora L. (Passifloraceae). Dissertação de Mestrado. Instituto de Biologia, Universidade Estadual de Campinas (UNICAMP), Campinas, SP, 81p.

KOSCHNITZKE, C. \& SAZIMA, M., 1997, Biologia floral de cinco espécies de Passiflora L. (Passifloraceae) em mata semidecídua. Rev. Bras. Bot., 20: 119-126.

LONSDALE, W. M., 1999, Global patterns of plant invasions and the concept of invasibility. Ecology, 80: 1522-1536.

LORENZ-LEMKE, A. P. et al., 2005, Phylogeographic inferences concerning evolution of Brazilian Passiflora actinia and P. elegans (Passifloraceae) based on ITS (nrDNA) variation. Ann. Bot. (in press).

MONDIN, C. A. \& BAPTISTA, L. R. M., 1996, Relações biogeográficas da tribo Mutisieae Cass. (Asteraceae), sensu Cabrera, no Rio Grande do Sul. Comun. Mus. Ciênc. Tecnol., Pontifícia Universidade Católica do Rio Grande do Sul (PUCRS), Ser. Bot., 2: 49-152.

MONDIN, C. A., 2001, Passiflora organensis Gardner (Passifloraceae), primeira citação para o Rio Grande do Sul. Pesquisas, Botânica, 51: 147-150.

MUSCHNER, V. C. et al., 2003, A first molecular phylogenetic analysis in Passiflora (Passifloraceae). Am. J. Bot., 90: 1229-1238.

PESSOA, S. V. A., 1994, Passifloraceae, pp. 315-322. In: M. P. M. Lima \& R. R. Guedes-Bruni (orgs.), Reserva ecológica de Macaé de Cima - Nova Friburgo - RJ: aspectos florísticos das espécies vasculares, Jardim Botânico do Rio de Janeiro (JBRJ), Rio de Janeiro.

PESSOA, S. V. A., 1997, Passifloraceae Mast., pp. 388-395. In: M. C. M. Marques, A. S. F. Vaz \& R. Marquete (orgs.), Flórula da APA Cairuçu, Parati, RJ: espécies vasculares, Série Estudos e Contribuições, Jardim Botânico do Rio de
Janeiro/Ministério do Meio Ambiente (JBRJ/MMA), Rio de Janeiro.

RAMBO, B., 1951, A imigração da selva higrófila no Rio Grande do Sul. Sellowia, 3: 55-91.

SACCO, J. C., 1962, Passifloraceae, pp. 7-29. In: A.R. Schultz (ed), Flora ilustrada do Rio Grande do Sul, Instituto de Ciências Naturais, Universidade Federal do Rio Grande do Sul (UFRGS), Porto Alegre.

SACCO, J. C., 1980, Passifloráceas, pp. 1-130. In: R. Reitz (ed), Flora ilustrada catarinense. Herbário Barbosa Rodrigues, Itajaí, SC.

SAZIMA, I. \& SAZIMA, M., 1989, Mamangavas e irapuás (Hymenoptera,Apoidea): visitas, interaçõese consequiências para polinização do maracujá (Passifloraceae). Rev. Bras. Entomol., 33: 109-118.

SEMIR, J. \& BROWN JR, K. S., 1975, Maracujá: a flor da paixão. Rev. Geogr. Univ., fevereiro: 41-47.

STRECK, E. V. et al., 2002, Solos do Rio Grande do Sul. Universidade Federal do Rio Grande do Sul/Empresa de Assistência Técnica e Extensão Rural (UFRGS/EMATER), Porto Alegre, 126p.

TEIXEIRA, M. B. et al., 1986, Vegetação, pp. 541-620. In: Instituto Brasileiro de Geografia e Estatística, Levantamento de recursos naturais, IBGE, Rio de Janeiro.

VARASSIN, I. G. \& SILVA, A. G., 1999, A melitofilia em Passiflora alata Dryander (Passifloraceae), em vegetação de restinga. Rodriguésia, 50: 5-17.

VARASSIN, I. G., TRIGO, J. R. \& SAZIMA, M., 2001, The role of nectar production, flower pigments and odour in the pollination of four species of Passiflora (Passifloraceae) in south-eastern Brazil. Bot. J. Linean Soc., 136: 139-152.

WILLIAMS, P. A. et al., 2000, Small mammals as potential seed dispersers in New Zealand. Austral Ecol., 25: 523-532. 